Original Research Paper

\title{
Optimalisasi Hasil Produksi Susu Kambing Peranakan Etawa melalui Ekonomi Kreatif Berbasis Mitra untuk Mendukung Pariwisata
}

\author{
Muhammad Khalid Rozani ${ }^{1}$, Nurlaili Agustin${ }^{1}$, Yudira Adhani ${ }^{1}$, Humaira Agustini ${ }^{1}$, Abdul Syukur ${ }^{2}$ \\ ${ }^{I}$ Program Studi Peternakan, Fakultas Peternakan, Universitas Mataram, Mataram, Indonesia \\ 2Program Studi Magister Pendidikan IPA, Universitas Mataram, Mataram, Indonesia
}

DOI: https://doi.org/10.29303/jpmpi.v4i2.721

Sitasi: Rozani, M. K., Agustin, N., Adhani, Y., Agustini, H., \& Syukur, A. (2021). Optimalisasi Hasil Produksi Susu Kambing Peranakan Etawa melalui Ekonomi Kreatif Berbasis Mitra untuk Mendukung Pariwisata. Jurnal Pengabdian Magister Pendidikan IPA, 4(2)

\section{Article history}

Received: 30 April 2021

Revised: 23 Mei 2021

Accepted: 01 Juli 2021

*Corresponding Author: Muhammad Khalid Rozani, Program Studi Peternakan, Fakultas Peternakan,

Universitas Mataram, Mataram, Indonesia;

Email: muhammadkhalidroz anib1do17202@gmail.com

\begin{abstract}
Pengembangan Pariwisata dinilai sebagai salah satu langkah untuk meningkatkan pendapatan masyarakat. Desa Ketapang Raya menjadi salah satu desa wisata di Kecamatan Keruak, Kabupaten Lombok Timur. Dikenalnya wilayah Ketapang Raya menjadi daerah wisata yang mengakibatkan meningkatnya pengunjung (wisatawan) ke daerah tersebut. Sehingga melalui Kuliah Kerja Nyata ini untuk mendukung sektor wisata di daerah Ketapang Raya yakni melalui ekonomi kreatif berbasis mitra dengan membuat produk olahan susu Kambing menjadi produk minuman Indogoat milk dan kecantikan berupa sabun susu Kambing Biolvy Body wash. Tujuan dari kegiatan ini untuk meningkatkan pendapatan masyarakat serta mendukung sektor wisata di desa Ketapang Raya. Kegiatan ini dilakukan dalam tiga tahap, yaitu tahap pertama penyediaan alat dan bahan, tahap kedua pembuatan produk dan tahap ketiga pemasaran serta pendekatan dengan masyarakat melalui sosialisasi. Hasil yang didapatkan dari program ini yaitu terjadinya peningkatan pengetahuan dan keterampilan mitra tentang wirausaha, mendukung peningkatan pariwisata. Diharapkan dari Program yang dijalankan dapat bermanfaat sehingga dapat meningkatkan pendapatan/penghasilan masyarakat sekitar wisata dan sebagai salah satu ikon di tempat wisata.
\end{abstract}

Keywords: Susu Kambing peranakan Etawa; Ekonomi kreatif; Indogoat milk; Biolvy body wash; Desa Ketapang Raya.

\section{Pendahuluan}

Indonesia merupakan negara yang dikenal dengan kepulauannya, sehingga beberapa daerah yang ada di kepulauan tersebut menjadikan sebagai objek wisata. Salah satu wilayah yang memiliki potensi wisata alam yaitu Nusa Tenggara Barat dikhususkan di bagian Lombok Timur. Salah satu objek wisata yang dapat di kunjungi salah satunya di desa Ketapang Raya, Kecamatan Keruak.

Desa Ketapang Raya merupakan daerah yang baru lahir secara de jure namun secara definitif sudah menjadi desa sejak Oktober 2010. Desa Ketapang Raya merupakan hasil dari pemekaran desa induk yaitu Desa Tanjung Luar, pada tanggal 12 Mei 2010. Desa Ketapang Raya diresmikan melalui peraturan Bupati Lombok Timur No. 16 Tahun 2010. Desa Ketapang Raya terdiri dari enam dusun yaitu Dusun Pelebe, Dusun Lungkak, Dusun Lungkak Selatan, Dusun Lungkak Utara Dan Dusun Telagebagik.

Desa Ketapang Raya merupakan suku mandar yang identik dengan pelaut sehingga pekerjaan sebagian besar masyarakat yaitu sebagai nelayan. Selain dari potensi dari bagian kelautan 
terdapat juga potensi pariwisata yang terdapat di desa Ketapang Raya. Program pengabdian Kuliah Kerja Nyata (KKN) di desa Ketapang Raya ini yaitu untuk optimalisasi hasil produksi susu Kambing peranakan Etawa melalui ekonomi kreatif berbasis mitra. Tujuan dari kegiatan ini untuk meningkatkan sektor wisata di Ketapang Raya dan beberapa desa-desa disekitar akan merasakan dampak dari pengembangan sektor wisata ini. Manfaat dari kegiatan ini yaitu dapat meningkatakan pendapatan masyarakat sekitar wisata dan sebagai salah satu ikon di tempat wisata.

Ternak Kambing ini sangat digemari oleh masyarakat untuk diternak karena ukuran tubuhnya tidak terlalu besar serta perawatannya yang relatif mudah, dan Kambing juga memiliki daya adaptasi yang tinggi dengan kondisi agroekosistem suatu tempat bahkan dengan kondisi lingkungan yang buruk pun Kambing masih mampu bertahan hidup (Sarwono, 2011).

Syamsu et al (2003) menyatakan bahwa Kambing mampu beradaptasi pada kondisi daerah yang memiliki sumber pakan hijauan yang kurang baik, dan merupakan komponen peternakan rakyat. Kambing Peranakan Etawa (PE) memiliki karakteristik sebagai ternak dwiguna dikarenakan selain menghasilkan daging, Kambing jenis PE juga menghasilkan susu yang rata-rata per hari mampu menghasilkan 700-1000 ml. Desa Ketangge Jeraeng merupakan salah satu desa yang memelihara Kambing PE, sehingga desa Ketangge Jeraeng merupakan salah satu desa penyuplai susu Kambing untuk mendukung sektor pengembangan wisata yang ada di desa Ketapang Raya.

Produksi susu Kambing tersebut dapat diolah menjadi beberapa produk yang dapat mendukung pariwisata di desa Ketapang Raya seperti produk minuman dan produk kecantikan yang nantinya akan ikut mendukung kegiatan wisata di desa Ketapang Raya.

\section{Metode}

\section{Waktu dan tempat Pelaksanaan}

Program KKN Tematik Era New Normal dengan tema kolaborasi antara P1000WB dengan wisata ini dilaksanakan pada tanggal 11 Januari sampai dengan 25 Februari 2021 yang berlokasi di Desa Ketapang Raya, Kecamatan Keruak, Kabupaten Lombok Timur.
Adapun metode pelaksanaan kegiatan kuliah kerja nyata (KKN) ini menggunakan metode pendekatan secara langsung dengan cara sosialisasi dan praktik, adapun tahapan pelaksanaannya yaitu:

\section{a. Persiapan Alat dan Bahan}

Adapun alat-alat yang dibutuhkan yakni: Gelas ukur (500 ml), Gelas ukur (100 ml), Spuit (20 ml), Wadah campuran, Pengaduk, Sarung tangan, Masker.

Adapun bahan-bahan yang dibutuhkan yaitu: Teksafon 1000 gram, Garam 500 gram, Metain $500 \mathrm{ml}$, Glukotain $250 \mathrm{ml}$, Gliserin 250 ml, Pewangi $250 \mathrm{ml}$, Ekstrak mutiara $200 \mathrm{ml}$, Sioside 200 ml, Susu Kambing 1000 ml, Air $2000 \mathrm{ml}$.

\section{b. Proses Pembuatan Produk}

\section{- Biolvy Body Wash}

Siapkan alat dan bahan yang dibutuhkan, Cuci tangan sebelum mulai produksi, selanjutnya tuangkan terlebih dahulu teksafon sekitar 400 gram. Selanjutnya ditambahkan garam non yodium 20 gram, selanjutnya tuangkan air secukupnya lalu diaduk sampai mulai terasa memadat, jika sudah terasa memadat dituangkan air secukupnya lagi lalu diaduk kembali, perlakuan yang sama sampai mendapatkan tekstur dan konsentrasi pada pencampuran sudah lembut, setelah itu tuangkan metain $40 \mathrm{ml}$ dan air secukupnya lalu diaduk lagi seperti langkah sebelumnya.

Selanjutnya tuangkan glukotain $20 \mathrm{ml}$ dan air secukupnya kemudian diaduk, selanjutnya ditambahkan gliserin $20 \mathrm{ml}$ aduk sampai mengembang, setelah itu ditambahkan sinoside $10 \mathrm{ml}$ dan air, aduk sampai merata sampai mendapatkan tekstur yang lembut.

Setelah bahan - bahan utama dicampurkan selanjutnya ditambahkan bahan ekstrak seperti bibit pewangi, ekstrak mutiara dan yang paling penting adalah susu Kambing segar $10 \%$ dari jumlah sabun cair yang dibuat. Setelah semua bahan sudah homogen dan tekstur sabun yang dibuat sudah lembut. selanjutnya, adonan sabun susu Kambing didiamkan selama $24 \quad-48$ jam untuk menghilangkan busa-busa yang masih ada pada adonan. Selanjutnya, sabun yang sudah didiamkan dikemas didalam botol yang berisi 
$250 \mathrm{ml}$ dan $500 \mathrm{ml}$. setelah pengemasan produk dipasarkan ke konsumen.

\section{- Indo Goat Milk}

Menyiapkan alat dan bahan yang dibutuhkan. Cuci tangan sebelum mulai produksi, tuangkan susu Kambing segar yang akan diproses (Pasteurisasi), siapkan stopwatch untuk mengukur waktu sekitar 10 menit, masak susu dengan panas api $90^{\circ} \mathrm{C}$, aduk beberapa kali untuk mencegah gumpalan pada susu yang sedang dimasak, didiamkan beberapa jam agar kondisi susu normal lalu dikemas pada kemasan yang sudah disediakan untuk didistribusikan ke konsumen.

\section{Hasil dan Pembahasan}

Pelaksanaan kegiatan Kuliah Kerja Nyata (KKN) Tematik Era New Normal dilaksanakan sejak pelepasan tanggal 11 Januari 2021 - 25 Februari 2021. Kegiatan KKN ini berlokasi di Desa Ketapang Raya, Kecamatan Keruak, Kabupaten Lombok Timur. Dengan jarak tempuh sekitar 61,3 $\mathrm{km}$ dan membutuhkan waktu sekitar 82 menit menggunakan sepeda motor dari Universitas Mataram. Untuk lebih jelasnya lokasi desa Ketangga Jeraeng dapat dilihat pada gambar 1 dan gambar 2 .

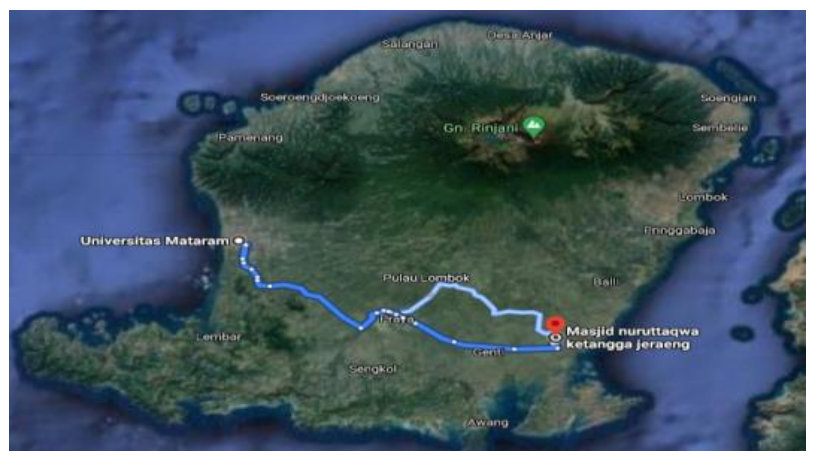

Gambar 1. Visualisasi jarak Universitas Mataram dengan lokasi KKN

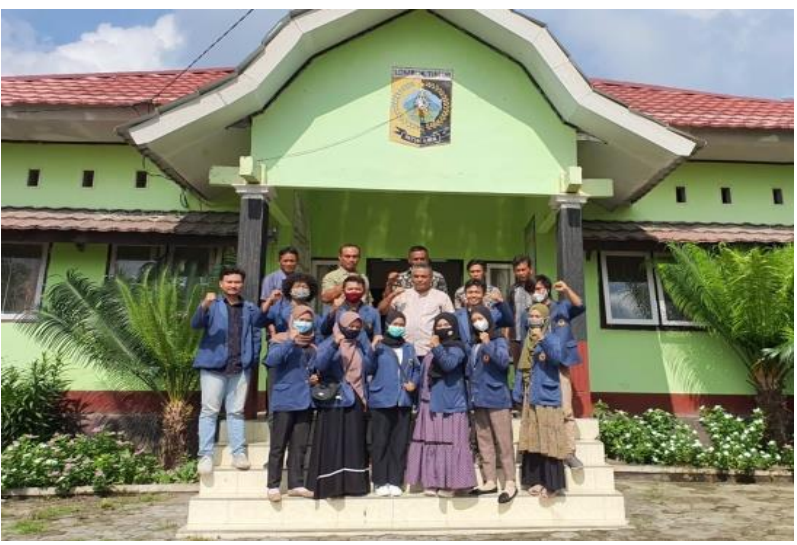

Gambar 2. Visualisasi penerimaan mahasiswa KKN di Desa Ketangga Jeraeng

Dari hasil observasi permasalahan yang ditemukan dikalangan masyarakat desa Ketangga Jeraeng adalah kurang mampunya melihat peluang usaha serta optimalisasi hasil produksi ternak berupa susu Kambing. Oleh karena itu, beberapa program kerja yang dilaksanakan pada Kuliah Kerja Nyata di desa Ketangga Jeraeng guna menjadi salah satu langkah untuk mendukung sektor wisata di Desa Ketapang Raya. Upaya peningkatan perekonomian masyarakat terlebih dahulu dilakukan survey potensi sumber daya alam yang ada di wilayah Ketangga Jeraeng, perencanaan usaha, pembuatan produk Indogoat Milk dan Biolvy Body Wash sebagai produk Merchandise untuk wisatawan yang berkunjung ke wilayah Ketapang Raya. Pemasaran melalui marketing online dan marketing offline, pengenalan produk ke beberapa instansi, dan pembukuan penjualan produk selama kegiatan KKN.

\section{Survey Potensi Peternakan di Wilayah Ketangga Jeraeng}

Sebelum pembuatan produk terlebih dahulu kami dari mahasiswa KKN melakukan survey sejauh mana potensi sumber daya alam berupa jumlah ternak Kambing khususnya jumlah indukan Kambing peranakan Etawa sebagai faktor utama produksi susu. Survey lokasi dilakukan selama 3 hari dengan dilakukannya pembagian wilayah yakni wilayah A, wilayah B dan wilayah C. Adapun masing-masing wilayah pembagian meliputi sebagai berikut, wilayah A: Ketagga Timur, Kemalik Jeraeng, dan Ketangga Barat. Wilayah B: Ketangga Kemalik, dan Ketangga Timuk Lauk. Wilayah C: Lingkok Ramben, Wates, dan 
Gelumpe. Dari hasil survey yang dilakukan, diketahui jumlah indukan ternak Kambing jenis PE berjumlah 150 ekor dengan rincian wilayah A: 70 ekor indukan, wilayah B: 50 ekor indukan, dan wilayah C: 30 ekor indukan.

\section{Pembuatan Produk Olahan}

Pembuatan produk olahan susu siap konsumsi dan produk olahan sabun mandi dilakukan pada minggu ke-2 sampai dengan minggu ke-5. Pembuatan produk ini meliputi beberapa tahapan seperti pasteurisasi susu, pencampuran bahan-bahan sabun, proses pengemasan hingga pelabelan pada kemasan produk, pengolahan produk Biolvy dan Indogoat Milk memperhatikan standar operasional yang dipelajari dari beberapa referensi di internet dan juga diskusi langsung dengan pelaku usaha produk kosmetik.

Produk olahan sabun (Biolvy) ini aman untuk digunakan semua jenis kulit, dikarenakan bahan - bahan yang digunakan pun tidak menggunkan bahan kimia yang keras, hal ini juga karena harapan kami dari mahasiswa KKN, produk kecantikan Biolvy ini dapat diimplementasikan oleh masyarakat setempat. Lebih jelasnya produk olahan Indogoat Milk dan Biolvy Body Wash dapat dilihat pada gambar 3 dan 4.

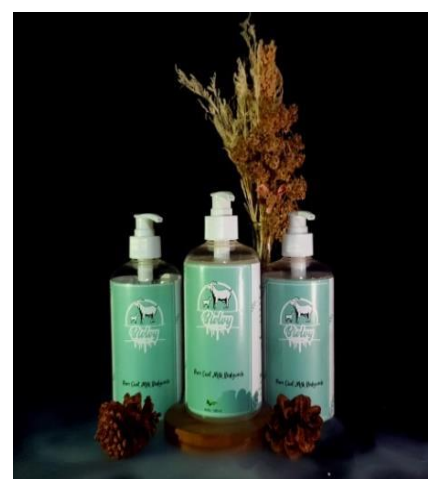

Gambar 3. Visualisasi produki Biolvy Body Wash

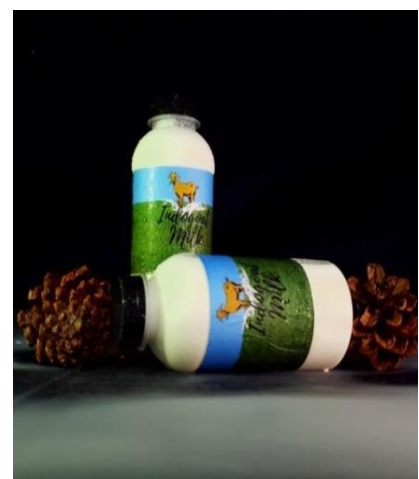

Gambar 4. Visualisasi produk Indogoat Milk

\section{Pemasaran produk}

Setelah pembuatan produk Biolvy Body Wash dan Indogoat Milk selanjutnya dibutuhkan pemasaran yang tepat, guna melancarkan kegiatan produksi, pemasaran ini sebagai langkah penentu dari sebuah perusahaan. Berhasil tidaknya perusahan ditentukan dari sejauh mana produk yang dihasilkan mampu diserap oleh konsumen, oleh karena itu sangat perlu menentukan pasar yang tepat untuk keberhasilan dalam berusaha, salah satunya dengan marketing online seperti Whatsapp, Instagram, Facebook, Shopee, Tokopedia.

Marketing online ini merupakan suatu langkah yang sangat dibutuhkan oleh pelaku usaha khususnya produk Biolvy dan produk Indogoat Milk, proses pemasaran (marketing online) lebih jelasnya dapat dilihat pada gambar 5 .

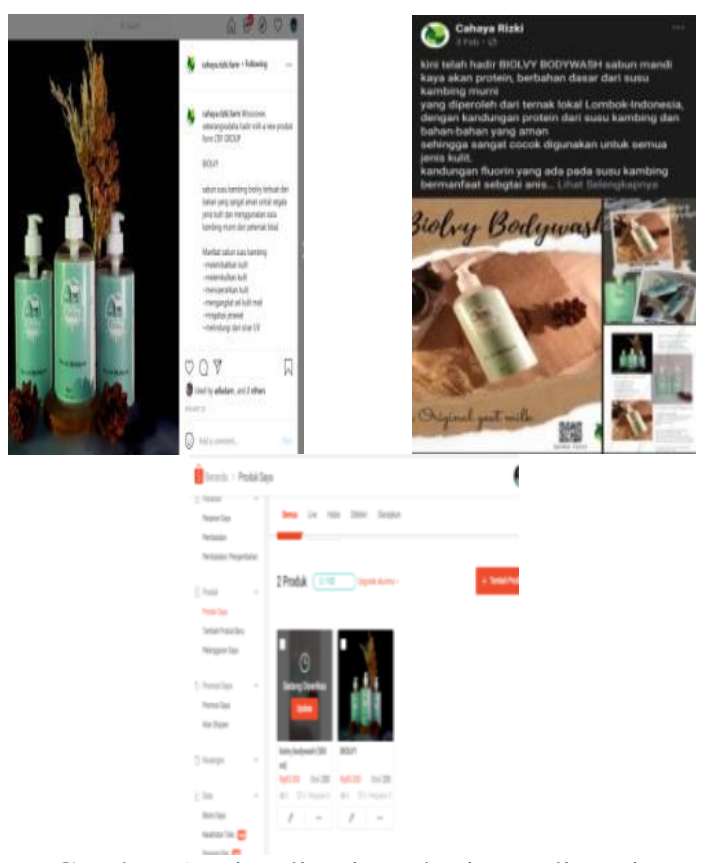

Gambar 5. Visualisasi marketing online via 


\section{Instagram, Marketplace, Shopee.}

Dari gambar 5 dapat dilihat dengan jelas beberapa platform yang digunakan untuk memasarkan hasil produk olahan Biolvy Body Wash dan Indogoat Milk, hal ini diharapkan mampu sebagai penunjang untuk meningkatkan penjualan produk. Selain pemasaran yang sudah dilakukan menggunakan marketing online, pelaku usaha juga perlu memperkenalkan produknya secara offline (secara langsung) hal inilah yang kami lakukan yakni memperkenalkan produk Biolvy Body Wash dan Indogoat Milk ke beberapa instansi dan ke beberapa tempat yang relevan dengan produk kecantikan. Lebih jelasnya proses pengenalan produk dapat dilihat pada Gambar 6.

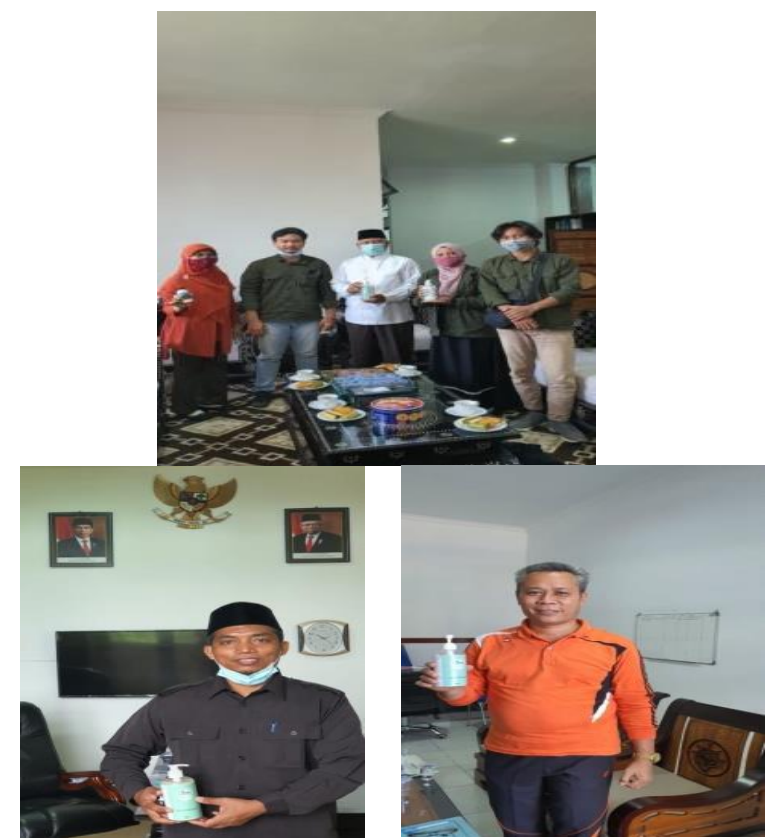

Gambar 6. Visualisasi pengenalan produk Biolvy ke Bupati Lombok Timur, DPRD Kabupaten Lombok Timur, dan Dinas Perindustrian Lombok Timur.

Selain dengan memperkenalkan produk Biolvy Body Wash dan Indogoat Milk secara langsung dengan Dinas atau Pemerintahan Daerah, kami juga melakukan bazar dan membuat sistem penitipan dibeberapa Reseller sehingga diharapkan dengan menggunakan sistem ini mampu untuk meningkatkan penjualan sesuai harapan, lebih jelasnya kegiatan bazar dan penitipan produk di Reseller dapat dilihat pada gambar 7.
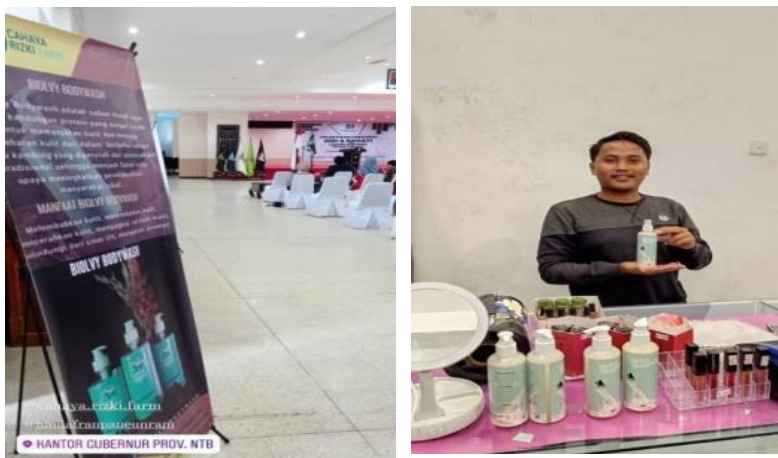

Gambar 7. Visualisasi bazar dan pengantaran produk di Reseller

\section{Pengantaran dan Pengiriman Produk}

Setelah melakukan marketing online maupun marketing online selanjutnya pengantaran dan pengiriman dilakukan pada minggu ke 6-7 sesuai dengan jadwal kegiatan dan waktu pemesanan produk, daya serap masyarakat yang, adapun pengantaran produk sesuai pesanan kebeberapa wilayah seperti, Lombok Timur, Mataram, hingga ke luar daerah seperti Cianjur Jawa Barat. Lebih jelas pengantaran produk dapat dilihat pada Gambar 8.

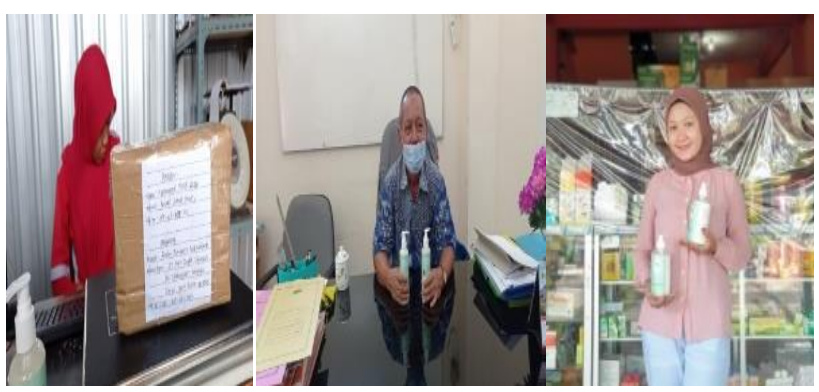

Gambar 8. Visualisasi pengantaran produk Biolvy Bodywah ke konsumen

\section{Pembukuan}

Pembukuan ini tidak hanya meliputi pembukuan hasil penjualan. Namun, pengeluaran serta biaya operasional juga dicatat dengan rapi guna membantu proses dalam kegiatan berwirausaha, layak atau tidaknya sebuah usaha diketahui dari bagaimana hasil, apakah sesuai dengan harapan. Sehingga, dalam hal ini dilakukan pembukuan dari minggu pertama sampai dengan minggu terakhir dilaksanakannya Kuliah Kerja Nyata (KKN). Hasil yang didapat cukup memuaskan dikarenakan setiap minggunya hasil penjualan dari kuantitas produk selalu meningkat, yang dikarenakan juga adanya 
inovasi yang kami hadirkan dari segi pengemasan produk, yang awalnya kemasan produk Biolvy hanya $500 \mathrm{ml}$ sedangkan daya serap konsumen kurang, karna harga yang relative tinggi. Setelah menghadirkan kemasan ukuran $250 \mathrm{ml}$ daya serap konsumen meningkat karna harga yang terjangkau oleh kalangan menengah kebawah.

\section{Kesimpulan}

Setelah dilakukannya survey potensi sumber daya alam diketahui Ketangga Jeraeng terdapat banyak Kambing Peranakan Etawa yang belum memiliki luaran produksi dari hasil susu sehingga perlu dilakukan optimalisasi, seperti pelaksanaan pengolahan susu Kambing segar menjadi produk olahan siap konsumsi dan produk kecantikan, untuk didistribusikan di wilayah Ketapang Raya sebagai produk merchandise ataupun souvenir kepada wisatawan. Mengoptimalkan hasil ternak yaitu susu Kambing yang selalu dihasilkan oleh indukan Kambing yang sedang laktasi tetapi tidak di komersialkan oleh peternak hal ini menyebabkan pendapatan peternak hanya dari penjulan ternak saja, dengan adanya upaya peningkatan melalui optimalisasi hasil ternak berupa susu Kambing. hal ini sangat mampu meningkatkan pendapatan peternak di Desa Ketangga Jeraeng, serta mampu menjadi pendukung sektor wisata di Ketapang Raya dari penyediaan produk peternakan sebagai produk kecantikan.

\section{Ucapan Terima Kasih}

Kami ucapkan Terimakasih kepada seluruh elemen masyarakat Desa Ketapang Raya dan Desa Ketangga Jeraeng serta Dosen Pembimbing lapangan sehingga program-program yang di rencanakan bisa terlaksana seperti apa yang diharapkan.

\section{Daftar Pustaka}

Data demografi jumlah penduduk.2019. https://www.desaketanggajeraeng.web.id/first/w ilayah.Diakses pada tamggal 15 febuari.

Kusumastuti, T.A., dan Bowo, S. 2014. Perkampungan Ternak Kambing Wahana Eduwisata dan Sentra Produksi di Pedesaan. Cetakan I. Gadjah Mada University Press: Yogyakarta.
Sarwono, B. 2011.Beternak Kambing Unggul.Cetakan I. Penebar Swadaya. Jakarta.

Santos, M. V., Y. Ma. and D. M. Barbano. 2003.Effect of Somatic Cell Count on Proteolysis and Lipolysis in Pasteurized Fluid Milk during ShelfLife Storage. J. Dairy Sci. 86: 2491- 2503.

UPT Peternakan dan kesehatan hewan.2019. Laporan Pemutahiran Data Populasi Ternak Kabupaten Lombok Timur.Lombok-indonesia. 